Post-print. Cite as: Kochan, J. (2015). "Objective Styles in Northern Field Science." Studies in History and Philosophy of Science 52: 1-12. http://dx.doi.org/10.1016/j.shpsa.2015.04.001

Creative Commons Attribution-NonCommercial-NoDerivs Licence (CC BY-NC-ND)

\title{
Objective Styles in Northern Field Science
}

\author{
Jeff Kochan(jwkochan@gmail.com) \\ Zukunftskolleg, Box 216, University of Konstanz, 78457 Konstanz, Germany
}

\begin{abstract}
Social studies of science have often treated natural field sites as extensions of the laboratory. But this overlooks the unique specificities of field sites. While lab sites are usually private spaces with carefully controlled borders, field sites are more typically public spaces with fluid boundaries and diverse inhabitants. Field scientists must therefore often adapt their work to the demands and interests of local agents. I propose to address the difference between lab and field in sociological terms, as a difference in style. A field style treats epistemic alterity as a resource rather than an obstacle for objective knowledge production. A sociological stylistics of the field should thus explain how objective science can co-exist with radical conceptual difference. I discuss examples from the Canadian North, focussing on collaborations between state wildlife biologists and managers, on the one hand, and local Aboriginal Elders and hunters, on the other. I argue that a sociological stylistics of the field can help us to better understand how radically diverse agents may collaborate across cultures in the successful production of reliable natural knowledge.
\end{abstract}

Key words: field sciences; styles of reasoning; cross-cultural science; incommensurability; epistemic neighbourliness; postcolonial science studies.

\section{Introduction: Incommensurability and Epistemic Neighbourliness}

If you leave Winnipeg travelling north down the Red River, you will eventually end up in the southern tip of enormous Lake Winnipeg. If you continue travelling much further north, until about midway along the eastern edge of the lake, you will arrive at the mouth of the Berens River. This is the home of the Berens River First Nation, a predominantly Ojibway/Saulteuxspeaking people. It was among them that Irving Hallowell conducted ethnographic fieldwork in the 1930s and 1940s.

Hallowell argued that the Berens River Ojibway were animists, in the sense that they recognised an a priori potentiality for animation, under specific conditions, in certain types of apparently inanimate objects. For example, he found that although the Berens River Ojibway did not experience stones as animate in general, they did experience specific stones as animate in specific contexts. A local informant told Hallowell that he had seen a big round stone move 
during a Midewiwin ceremony. The animate behaviour of the stone under these circumstances was considered a manifestation of the magico-religious power of the Midé (Hallowell, 1969, p. $55)$.

Hallowell (1969, p. 54) viewed this situated animism as a "radical departure from the framework of our thinking." Indeed, he argued that Berens River Ojibway even experienced stones as capable of much more than self-movement, offering the following anecdote as evidence.

A white trader, digging in his potato patch, unearthed a large stone similar to the one just referred to [as moving during the Midewiwin ceremony]. He sent for John Duck, an Indian who was the leader of the wábano, a contemporary ceremony that is held in a structure like that used for the Midewiwin. The trader called his attention to the stone, saying that it must belong to his pavilion. John Duck did not seem pleased at this. He bent down and spoke to the boulder in a low voice, inquiring whether it had ever been in his pavilion. According to John the stone replied in the negative. (Hallowell, 1969, p. 56.)

Hallowell $(1969$, p. 56) argues that "[s]peaking to a stone dramatizes the depth of the categorical difference in cognitive orientation between the Ojibwa and ourselves. [...] In the anecdote describing John Duck's behavior, [...] his use of speech as a mode of communication raises the animate status of the boulder to the level of social interaction common to human beings."

In laying out the problem space to be addressed in this paper, I want to highlight two aspects of Hallowell's discussion. The first is his emphasis on the radical difference between “our" cognitive framework and that of the Berens River Ojibway. Hallowell $(1969$, p. 51) characterises this as a difference in "metaphysics of being." In his view, the Berens River Ojibway structure the intelligibility of their experience within a metaphysical worldview which is dramatically different from "ours." Each side has its own distinct "unified cognitive outlook" (Hallowell 1969, p. 54). Hallowell (1969, p. 78) furthermore argues that the Berens River Ojibway live and act within a single "psychological field." His emphases on cognition, psychology, and metaphysics together suggest that what Hallowell $(1969$, p. 50) calls "ethnometaphysics" is the study of unified and discrete conceptual schemes or mental worlds.

The second aspect of Hallowell's discussion which I would like to highlight appears to immediately place this comparative methodology into doubt. It points to a blind spot in Hallowell's analysis, one exemplified above all by his phrase: "In the anecdote describing John Duck's behavior [...]." Hallowell neglects the fact that the anecdote does more than describe 
John Duck's behaviour. It also describes the behaviour of the white trader. And the trader's behaviour hardly suggests that he views John Duck as inhabiting a mental world radically different from his own. Indeed, the trader seems to accept the fact of Duck's situated animism, and, like any good neighbour, he takes action to reunite Duck with what he presumes to be Duck's personal belonging. At the level of behaviour, then, the anecdote shows scarce evidence for an insurmountable alterity between Duck and the trader. This is not to say that there is no important difference in their respective worldviews. It is rather to suggest that such conceptual or metaphysical differences may prove secondary when one's main concern is to establish and maintain good neighbourly relations, to get along with one another in a common environment.

In this paper, I will explore the prospects for what I will call epistemic neighbourliness in the context of the northern field sciences. It must be emphasised right from the start that the prospects are not good. But there is a difference between "not good" and "hopelessly impossible," and it is on this thin distinction that I will balance the weight of my argument. I wish to make plausible the idea that radical conceptual alterity need not necessarily poison the prospects for cross-cultural scientific collaboration. Objective scientific knowledge may be successfully co-produced in contexts of radical conceptual difference, that is, in contexts of conceptual incommensurability. ${ }^{1}$ I suggest that whether or not this becomes possible depends, in significant part, on epistemic neighbourliness. The word 'neighbour' derives from the Old English nēahgebūr, nēah meaning "near" and gebūr meaning "farmer" or "inhabitant." An inhabitant is one who dwells in rather than merely occupies a place (L. inhabitare, in- "in" + habitare "dwell"). The concept of epistemic neighbourliness is thus meant to denote a relation between persons dwelling near to one another, a relation which is constitutive of their shared knowledge of a common place.

The anthropologist Tim Ingold uses the concept of a "dwelling perspective" to describe the ways in which field anthropologists perceive their research environment. According to Ingold, this perspective "allows the fieldworker and local people to inhabit a common ground of experience, even though they each may bring to bear a radically different conceptual frame to the task of its interpretation" (Ingold 2000, p. 167). This common ground of experience, when it exists, may allow for successful epistemic collaboration even in cases of strong conceptual difference. However, such collaborations require not just the shared susceptibility of epistemic agents to a common environment, but also their mutual susceptibility to one another (cf. Barnes

\footnotetext{
${ }^{1}$ On this point, I am in agreement with Helen Verran (Verran, 2002, p. 757, and 2013, p. 144). However, where she tries, tentatively and on the basis of her rare expertise, to prescribe ways for overcoming such difference, I wish only to describe the modest and often neglected ways in which it has already been overcome.
} 
2001, p. 24). Hence, these collaborations are a suitable topic not only for ecology and psychology, but also for sociology. I thus employ epistemic neighbourliness as a sociological concept, one which emphasises the interpersonal dependencies of collaborative epistemic work, especially the ways in which those interdependencies serve both to stabilise and to co-ordinate the individual experiences of distinct agents dwelling in a common environment. Epistemic neighbourliness puts a sociological spin on Ingold's dwelling perspective, and extends its reach beyond the narrow scope of anthropological fieldwork. I will develop this concept through a discussion of several examples of biological field science from the Canadian North, and I will offer some remarks on the utility of epistemic neighbourliness for the study of field science in general. To begin, however, I must first secure the autonomy of field science as a distinct subject matter for social studies of scientific practice.

\section{Decolonising the Field Sciences}

The historical and sociological study of field science has been colonised by a specific and influential strand of laboratory studies. This colonisation process was not a surreptitious one. Advocates of these laboratory studies made it quite clear what they were doing: "Give me a laboratory and I will raise the world," declared one well-known champion. After asserting that most new sources of knowledge come from the lab, Bruno Latour concluded that the social and political power of science results from scientists' organised goal of "transforming society into a vast laboratory" (Latour, 1983, pp. 160, 167). Because epistemic power is constituted in laboratory practices, its extension throughout society necessarily depends on the extension of those practices beyond the walls of the laboratory. ${ }^{2}$

The imperialism of such laboratory studies has not left field studies unaffected. Indeed, the enthusiastic uptake of Latour's model has led Sergio Sismondo, in his survey of the state-ofthe-art in STS, to conclude that "[a] substantial part of the work of field research is work to turn the field into a laboratory" (Sismondo, p. 118). Latour (1990, p. 54) has even suggested that the global expansion of European power in the modern era may be viewed as a "bigger scale

\footnotetext{
${ }^{2}$ Indeed, David Turnbull and Helen Verran observe that the laboratory accounts of both Latour and Joseph Rouse (1987) "have standardized forms of knowledge swarming unimpeded out of the laboratory. As they see it, resistance is useless" (Turnbull and Watson-Verran 1995, p. 129). Latour (1987, p. 93) has furthermore written that the "layman is awed by the laboratory set-up, and righty so. [...] [C]onfronted by laboratories we are simply and literally impressed. We are left without power.” For general critiques of Latour and Rouse, see Kochan (2010 and 2011) respectively.
} 
experiment" which depended on the simultaneous extension of "micro-scale experiments" into colonised territories. For example, according to Latour (1990, pp. 53f., 76), Peron, the official zoologist of the 1802 Baudin expedition, used lab techniques and instruments to establish European power on the Tasmamian coast, with Aboriginal Tasmanians being eventually "wiped out" as a result.

Sismondo (2010, p. 118) is surely right that "insights gathered from laboratory studies also apply to field contexts." Yet this does not justify the stronger claim that field sites should be studied as extensions of the lab. Attempts by Latour and his followers to assimilate the dynamics of the field into their model of the laboratory threaten to erase the distinctiveness of scientific field practices. Indeed, not all students of the field have proven themselves ready to surrender the autonomy of their subject to the imperialism of these lab studies. They have instead insisted that field sites have been, and continue to be, a unique source of new scientific knowledge. Above all, in contrast to laboratory practices, field practices are less easily insulated from the vagaries of the broader social and political circumstances in which they are situated. As Henrika Kuklick and Robert Kohler have observed:

Unlike laboratories, natural sites [...] are public spaces, and their borders cannot be rigorously guarded. They are inhabited by very different sorts of people, who are going about very different sorts of business. [...] Thus, cultural translation remains a persistent and pervasive possibility in the field sciences, far more than in the laboratory disciplines. (Kuklick and Kohler, 1996, p. 4.)

Because of their heterogeneity and the irremediable fluidity of their natural boundaries, the field sciences present a subject matter importantly different from that of the lab. Kohler $(2002$, p. 6$)$ has described this as a difference in "cultural geography," arguing that "[1]aboratory workers eliminate the element of place from their experiments[, while] [f]ield biologists use places actively in their work as tools." "Richard Powell has, in turn, emphasised the "epistemic peculiarities" of the field sciences (Powell, 2002, p. 267), while Julie Cruikshank has pressed home the importance of these peculiarities specifically in the case of northern field science: "A dominant narrative of northern science has long portrayed the Arctic and Subarctic as a kind of super-laboratory, but environmental sciences [...] are more accurately characterized as field sciences than as closed, controlled laboratory sciences" (Cruikshank, 2001, p. 380).

\footnotetext{
${ }^{3}$ Vetter (2011) collects several historical essays inspired by Kohler's pioneering efforts to demonstrate the specificities of the field sciences.
} 
In response to Kohler's recent lament that "there has been little effort to treat the diversity of [scientific] practices systematically and comparatively," I attempt in this paper to shed sociological light on the differences between laboratory and field practices (Kohler, 2011, p. 229). Indeed, I will argue that the comparative openness and unpredictability of field sites may be viewed not just as a geographical, ecological, or psychological difference, but also as a sociological difference. Unlike the largely private and carefully controlled space of the lab, field sites are typically public sites representing a diverse range of interests. Field scientists may find it both necessary and useful to recognise these diverse interests in the conduct of their research. Such recognition marks a distinct difference between the field sciences and Latour's influential model of the lab as an "agonistic" arena, marked by "trials of strength" in which scientists struggle to shift power in their own favour, especially as they seek to extend their practices into society (Latour and Woolgar 1979, p. 237; Latour 1987, p. 78). ${ }^{4}$ This is a distinction between epistemic agonism, on the one hand, and epistemic neighbourliness, on the other, between contestation and collaboration as the central social dynamic giving shape to scientific research. Through a sociological appropriation of work by the philosopher Ian Hacking, I propose to address this as a difference in scientific style.

\section{Objective Styles}

Hacking argues for the existence of different styles of scientific reasoning, each guided by its own distinctive techniques of verification. These techniques provide the basis for

\footnotetext{
${ }^{4}$ Addressing the influence of the Latourian model, Donna Haraway urges STS practitioners to set aside "the mind-numbing militarized games of endless agonistic encounters and trials of strength" (Haraway, 1994, p. 69). Steven Shapin, in turn, notes the historiographic limitations of "the militaristic and imperialistic language that is so characteristic of Latour's work" (Shapin, 1998, p. 7). For similar criticisms, see: Berg (1996, p. 254); Elam (1999, p. 21); Harding (2008, pp. 42-43); Kochan (2010); and Star (1991, p. 48). Latour's rhetoric softened over time, but he nevertheless continued to model scientific practice on the basic dispositions of "Machiavellian primates," who "manipulate one another to survive in groups" (Latour 1999, p. 211; cf. Latour and Strum 1987, p. 123). His 1999 chapter on field science in the Amazon is free from agonism, but not because he did not observe any there: "I will not deal at length with the politics surrounding this expedition [...]. I am going to omit many aspects of this field trip that pertain to the colonial situation" (Latour, 1999, p. 27). Indeed, Latour's goal in that chapter was not an ethnography of field science, but the philosophical usurpation of a "Kantian" theory of reference. For a critique, see Kochan (2015).
} 
objective scientific knowledge. Hacking takes the inspiration for his notion of styles from Alistair Crombie's historical study of "styles of scientific thinking" (Hacking, 1982, p. 50). However, Hacking (1992, p. 3) swaps Crombie's word "thinking" for the word "reasoning" because, he says, thinking is too much in the head for his liking. But even "reasoning" is not good enough for Hacking (1992, p. 3): "[It] has too much to do with mind and mouth and keyboard; it does not [...] sufficiently invoke the manipulative hand and the attentive eye." The term "styles of reasoning" should conjure up visions of science as an engaged activity, a bodily involvement, or even intervention, in the world. Scientific styles should be understood in terms of embodied practices, or techniques, rather than conceptual content: "The focus is on how we find out, not on what we find out" (Hacking 1992, p. 1). A style is thus different from a conceptual scheme. Indeed, it is the field of practical engagement within which conceptual statements may, or may not, be experienced as intelligible, as forming a coherent and meaningful cognitive whole. In Hacking's terms, any such statement, once experienced as intelligible within the scope of a particular style, becomes "up for grabs, a candidate for being true-or-false" (Hacking 1982, p. 48). In other words, within the scope of a style, we recognise the statement as something for which we have a technique by which to determine its truth value, that is, its status as a true or as a false statement. In a nutshell, Hacking's central idea is that a scientific statement can be experienced as intelligible only within the scope of a particular style; it makes sense to us only because we possess a technique by which to verify its truth value. A statement for which we have no such technique will simply not make sense within that style; we will experience it as unintelligible, literally, as nonsense. ${ }^{5}$

A crucial idea in Hacking's stylistics is that styles of reasoning emerge from specific micro-social and micro-historical circumstances. Because of this, there is, for Hacking, an important role for historians and sociologists to play in illuminating the nature of scientific styles. This role, however, has strict limits. Indeed, according to Hacking, in contrast to the emergence of styles, to which historians and sociologists may suitably attend, the persistence of styles is a topic best left to philosophers: "the philosopher can describe the techniques, which become autonomous of their historical origins, and which enable styles of reasoning to persist at all" (Hacking, 1992, p. 19). These styles persist because they are enabled by techniques which have become self-stabilising. This self-stabilisation establishes the style's autonomy not only from its historical origins, but from its social origins as well: "a style becomes autonomous of

\footnotetext{
${ }^{5}$ Peter Dear has given abundant attention to the role of intelligibility in the history of science, but without reference to Hacking's stylistics (see Dear, 2003, 2006).
} 
the local microsocial incidents that brought it into being" (Hacking, 1992, p. 17). ${ }^{6}$ According to Hacking, the persistence of a style, its stability over time, is an appropriate topic for neither historians nor sociologists. Later, I will challenge the legitimacy of the methodological distinction Hacking draws between history and sociology, on the one side, and philosophy, on the other. In the meantime, let me emphasise what is of genuine sociological interest in his account of styles.

As we will see in the next section, Hacking's stylistics provides us with a powerful tool for studying science in action, particularly science in the field, where radically different understandings of nature may come into contact with one another. In such cases, often crosscultural in character, issues of mutual unintelligibility can become a pressing concern, and the link Hacking makes between intelligibility and techniques of verification gives us a valuable analytical tool for addressing that concern. Most importantly, Hacking's stylistics gives us a way to understand incommensurability in science, not as a contradiction between conceptual schemes, but as a conflict between contrasting techniques for making sense of nature, for rendering it intelligible. It is the persistence of these conflicting techniques, the way their respective technicians experience them as self-stabilising and self-evident resources for producing natural knowledge, which makes the conflict between them feel insurmountable. Hacking is responding to this experience of persistence when he claims that a style becomes "autonomous" of the social and historical conditions from which it emerged. We experience the enabling techniques of a style as falling outside our control, as possessing a life of their own, as powerfully shaping our reasoning with a compulsive force which seems to outstrip the finite power of our own subjective will. This compulsive force is the objective force of necessity. In the context of scientific styles, Hacking seems to view this as a practical necessity, a stabilised feature of our embodied reasoning techniques. This objective force may compel us to protect the self-evident integrity of our own reasoning techniques against the perceived unintelligibility of other traditions. In such circumstances, we experience the relation between our tradition and the other as one of incommensurability. Hacking's stylistics thus allows us to reconceptualise incommensurability as the experience of one set of techniques as being necessary for the production of a specific domain of scientific knowledge, and another set of techniques as being

\footnotetext{
${ }^{6}$ Hacking (2012, p. 605) has more recently defined the autonomy of styles like this: "No foundation. The style does not answer to some external canon of truth independent of itself." If 'style' were replaced by 'social group', this definition would nicely capture the micro-social bootstrapping favoured by sociologists of scientific knowledge (see Barnes, 1983). But Hacking (2012, pp. 606-607) tries to obstruct this move by insulating styles from sociological explanation, preferring instead to speak of "cognitive" and "ecological" causes.
} 
hopelessly unproductive, or perhaps even destructive, of that knowledge. This casts powerful new light on the causes of incommensurability. Where I disagree with Hacking, however, is on the question of whether or not such an experience can be explained (necessarily but not sufficiently) in sociological terms. I believe that it can.

Indeed, I argue that a sociological stylistics is enormously useful when our goal is to explain the cross-cultural encounters most characteristic of scientific field sites. If we view styles as autonomous of micro-sociological circumstances, as Hacking advises us to, we risk suppressing the socio-historical dynamics by which individual subjectivities become coordinated in the interests of stable, objective knowledge. ${ }^{7}$ In the typically diverse contexts of the field sciences, this process of coordination may often involve a significant investment in cross-cultural communication and cooperation. It may, in other words, place a premium on epistemic neighbourliness. In such contexts, radical epistemic difference may thus present a resource, rather than an obstacle, for the production of objective natural knowledge.

I now turn to a recent example of northern field science. It will quickly become clear just how difficult it can be to locate traces of the epistemic neighbourliness I have proposed as central to the style of reasoning distinctive of the field sciences. The power and pervasiveness of lab practices have indeed diminished the independence of the field. Nevertheless, systematically identifying and highlighting these traces of epistemic neighbourliness, as well as developing an account of the conditions which enable and sustain them, will help us in the task of decolonising the field sciences. Here I take only a few modest first steps in pursuit of this larger goal.

\section{The Ruby Range Sheep Steering Committee}

If one is interested in finding a natural field site inhabited by very different sorts of people who are going about very different sorts of business, then one could do far worse than to look to the Canadian North. ${ }^{8}$ Not only is this a landscape teeming with scientific research activity, it is also home to Aboriginal populations whose unique ways of life are still very much alive and whose political voice has been gathering strength since the 1970s. Indeed, various

\footnotetext{
${ }^{7}$ For discussions of the role played by emotion in this social process of epistemic coordination, see Kochan (2013 and 2015b).

${ }^{8}$ Field science in Northern Canada has received increasing attention from social scientists and historians in recent years. For examples, see: Bravo (1996 and 2000); Cruikshank (2001 and 2005); Powell (2007 and 2008); and the broad engagements of the Nouvelle Initiative
} Canadienne en Histoire de l'Environment / Network in Canadian History and Environment (NiCHE), catalogued at $<$ niche-canada.org $>$. 
levels of Canadian and Aboriginal government have, in recent years, publicly encouraged programmes of co-management and joint research in the North, programmes which bring together scientists and Aboriginal peoples in an effort to develop a collaborative, cross-cultural form of scientific practice which accommodates the interests of the region's diverse local stakeand rights-holders. ${ }^{9}$ For example, as Michael Bravo has noted, the government of the Northwest Territories now insists on "the importance of balancing scientific and indigenous voices by treating them as political and cultural equals" (Bravo, 2000, p. 469). In my terminology, these are initiatives deliberately, if often imperfectly, reflecting the principles of epistemic neighbourliness, the recognition that members of radically different cultural traditions may jointly inhabit, and share a common epistemic interest in, the same natural environment. In this section, I will discuss one such initiative: The Ruby Range Sheep Steering Committee, which operated in the Southwest Yukon in the second half of the 1990s.

The Ruby Range Sheep Steering Committee was established in 1995 in response to concerns raised by the Aboriginal Kluane First Nation about declining Dall sheep populations in the nearby Ruby and Nisling mountain ranges. The committee was comprised of a diverse membership, including, but not limited to, government wildlife biologists and resource managers, environmentalists, big game outfitters, and local First Nations Elders and hunters. The committee also included the anthropologist Paul Nadasdy, whose ethnographic account of the committee process serves here as my main resource (Nadasdy, 2003).

If styles of scientific reasoning were at play in the deliberations of the Ruby Range Sheep Steering Committee, then there should be some evidence that committee members were excluding specific statements from those deliberations because they had no technique by which to judge their truth or falsity. Hacking $(1992$, p. 13) argues that the best theory of truth and meaning for the analysis of statements produced within a style of reasoning is a verification theory. According to this theory, the meaning of a statement is established by the method or technique by which its truth or falsity is determined. The implication of this is that those statements excluded from deliberation, for lack of a technique by which to determine their truth or falsity, are experienced as scientifically unintelligible, that is to say, as statements which cannot be properly understood and utilised in that particular context. In fact, there were many such statements made by members of the Ruby Range Sheep Steering Committee.

\footnotetext{
${ }^{9}$ Stephen Bocking (2011) offers a useful history of these developments, while Milton Freeman (1985) provides an interesting and pioneering early perspective. For specific examples of such efforts in Canada, see: Inglis (1993); Michel and Gayton (2002); Smith (2004); and Spaeder and Feit (2005). For international examples, see Fortmann (2008).
} 
One example concerns the question of just how severe the drop in the number of Dall sheep in the Ruby and Nisling ranges actually was. The population counts of the wildlife biologists only went back as far as 1974, when they had conducted their first aerial survey. In contrast, the knowledge of First Nations hunters, preserved in memory and oral history, went back much further, and every single hunter who spoke to the committee insisted that the sheep population was already in significant decline well before 1974 (Nadasdy 2003, p. 190). Yet the biologists did not accept the hunters' oral history as grounds for temporally extending the biological data. As Nadasdy (2003, p. 191) writes, "biologists simply could not accept that testimony as a basis for action because they had no way of independently verifying the sheep population had ever been any higher than the 1980 level." In other words, the biologists had no technique by which to judge the reliability of the hunters' statements, and so they said that they could not accept those statements as relevant to the committee's concerns. On Hacking's verificationist account of meaning, because the biologists could not, by their own lights, establish the truth or falsity of the hunters' testimony, they were unable to ascribe to it any determinate scientific meaning. ${ }^{10}$

Nadasdy (2003, p. 213) also notes a more extreme example of the same phenomenon, this time with respect to the testimony of First Nations Elders:

If an elder spoke, it was much more likely that he or she would be met with an uncomfortable silence. Then, after a short pause, the conversation would resume as if he or she had never spoken. I do not believe that this was the result of actual disrespect or contempt on the part of the non-First Nations [committee] members. Frequently, they either could not understand what the elders were saying or failed to recognize its relevance. They did not know how to respond, so they did not respond at all. ${ }^{11}$

\footnotetext{
${ }^{10}$ Interestingly, in a 2005-06 report on Dall Sheep habitat loss in the Ruby Range, another government scientist showed no reluctance to cite what appears to be the same hunters' testimony: "Aerial survey estimates show the Ruby Range sheep population has declined fairly steadily since the mid-1980s. Furthermore, local oral knowledge suggests the population was likely double the initial survey estimates made during the 1950s (Ruby Range Sheep Steering Committee, unpublished report)" (Weir, 2005-06, p. 23). Scientific judgements of the reliability of these hunters' testimony thus appear to have been a strongly contingent matter.

${ }^{11}$ Verran (2013, p. 144) describes these awkward silences in cross-cultural scientific contexts as moments of "epistemic disconcertment." Cruikshank (1998, pp. 45-47) recounts a similar encounter between archaeologists and the late Southern Yukon Elder, Mrs. Annie Ned, CM.
} 
Although these two examples may suggest that the Ruby Range Committee was guided by an objective scientific style, because the testimony of First Nations committee members was in both cases excluded from consideration one could conclude that the style in question failed to properly reflect the heterogeneity and fluidity of the local field site, that there was an absence of epistemic neighbourliness in the proceedings of the committee. Indeed, on the basis of such examples, Nadasdy (2005, p. 223) concludes that the heterogeneity of the Ruby Range Committee was largely a smokescreen obscuring the machinations of an imperialistic Canadian state. An epistemic agonism more characteristic of the lab concealed itself behind a rhetoric of epistemic neighbourliness more politically appropriate to the cultural diversity of the natural field site and the collaborative mandate and legal context of the committee.

Yet, although there is ample empirical evidence justifying Nadasdy's pessimism, his ethnography also includes examples which paint a more open and flexible picture of the committee's work. One such example concerns the committee's use of aerial surveys to reckon the size of the Dall sheep population. Members of the Kluane First Nation accompanied biologists on these surveys. They were horrified by the effects the low-flying helicopter had on the sheep: "All of them recalled watching sheep run in terror at full speed over very dangerous terrain" (Nadasdy, 2003, p. 202). Some Kluane people also expressed their scepticism about the reliability of the aerial survey. With sheep scattering in all directions, it would be easy to miss some, or to count the same sheep twice. Indeed, one Kluane member participating in a flight kept his own count independently of the biologists, and ended up with a significantly lower number (Nadasdy, 2003, p. 202). ${ }^{12}$ Partly in response to these concerns, the biologists modified their surveying method, moving it from June to July, when the sheep would have moved to less treacherous ground and hence be less likely to injure themselves as they fled from the helicopter. This change in the conditions under which data were collected created a discontinuity with data from previous years. The biologists agreed to this change despite the new methodological difficulties with which it then forced them to cope.

A more dramatic case of co-operation involved the July 1996 aerial survey, when government biologists counted 147 fewer sheep than they had the previous year, indicating a population decrease of almost 26 percent (Nadasdy, 2003, p. 186). In the autumn of that same year, a local big game outfitter, who was also a member of the Ruby Range Sheep Steering

${ }^{12}$ Given their frequent criticism of the biologists' quantitative understanding of sheep (Nadasdy, 2003, pp. 108, 128), this incident suggests a willingness by Kluane members to restrain their own indigenous understanding of sheep as intelligent, social beings in the interests of scientific collaboration. However, as we will see shortly, this act of epistemic neighbourliness was not reciprocated by the biologists, who ignored the hunter's significantly different sheep count. 
Committee, organised his own ground survey, obtaining results similar to those of the biologists, except in one management subzone, where his group counted 100 sheep where the biologists had counted none. The government biologists agreed to modify their own survey data, incorporating the data provided by the outfitter. As Nadasdy (2003, p. 198) points out, this modification required "creative interpretation" on the part of the biologists in order to overcome the "technical difficulties" involved in bringing together two disparate sets of data. Furthermore, Nadasdy (2003, p. 198) writes that "[b]iologists had accepted the outfitter's numbers at face value and were willing to base their actions (or non-action, in this case) on them - without requiring any additional 'proof' - despite the fact that those numbers differed radically from their own." This example illustrates the willingness of wildlife biologists to downplay the importance of their own methods of verification in order to facilitate productive co-operation with a non-scientific member of the steering committee. It thus suggests that the style of scientific reasoning characteristic of the field sciences may involve more methodological flexibility than does the style often attributed to the lab sciences. Yet, at least in the present case, this flexibility seems $a d$ hoc rather than principled. As Nadasdy (2003, p. 202) observes, government biologists displayed no similar willingness to consider the independent data provided by the Kluane member, mentioned earlier, who had accompanied them on one of their survey flights. Furthermore, the biologists similarly disregarded the unanimous statement made by Kluane hunters that the Dall sheep population had been in dramatic decline since long before the biologists began their aerial surveys in the 1970s, arguing that they had no way of independently verifying that statement.

Traces of epistemic neighbourliness can be found in the proceedings of the Ruby Range Sheep Steering Committee, but their application appears to have been piecemeal, lacking the kind of consistency and coverage one would expect from a self-stabilising style of reasoning. The question thus arises of what blocked this process of self-stabilisation, what compromised the committee's own official commitment to epistemic neighbourliness, to the co-production of shared natural knowledge in spite of the presence of dramatic cultural difference.

\section{The Perils of Overblown Theorising}

The preceding example demonstrated the utility of Hacking's stylistics of scientific reasoning for an analysis of the field sciences. A style is composed of the techniques used by practitioners to make sense of statements. Only intelligible statements can become candidates for objective agreement or disagreement. If a statement cannot be captured within the scope of those techniques, practitioners will experience it as scientifically meaningless, and so 
impossible to evaluate in objective terms. What the Ruby Range example has not demonstrated is the presence of a style unique to the field sciences. The traces of epistemic neighbourliness found in the proceedings of the Ruby Range Sheep Steering Committee are not consistent and stable enough to constitute a style of reasoning. This was in spite of the committee's own official mandate to pursue cross-cultural scientific collaboration.

Nadasdy's ethnographic account provides a plausible explanation for this failure. $\mathrm{He}$ gives much attention to the way the internal social dynamics of the committee served to systematically reduce its own epistemic heterogeneity, the way those dynamics tended to powerfully exclude voices which did not fit the pre-existing epistemic standards of government wildlife biologists. Nadasdy (2003, p. 264) writes that Aboriginal members of the committee "ha[d] little choice but to engage government biologists and lawyers on terms dictated by the state." Indeed, he furthermore draws the general conclusion that projects touting cross-culture science in the Canadian North should, in fact, be viewed as "subtle extensions of empire, replacing local Aboriginal ways of talking, thinking and acting with those specifically sanctioned by the state" (Nadasdy 2005, p. 228). Despite the optimism often accompanying such initiatives, at the end of the day "First Nations people have simply been given their own 'slot' in the bureaucratic system" (Nadasdy 2005, p. 225). According to Nadasdy, then, the Ruby Range Sheep Steering Committee, as an exercise in cross-cultural science, never really had a chance. The epistemic dynamics of the committee served to systematically efface the cultural heterogeneity and fluid boundaries which were characteristic of its field site.

Nadasdy's critique can help us to better understand the shortcoming in Hacking's account of the objectivity of styles. Recall that, for Hacking, styles become stable by winning autonomy from the social and historical circumstances from which they have emerged. The emergence of a style may be a topic for historians and sociologists, but its persistence is a topic only for philosophers. I said earlier that I would challenge this division of labour. Indeed, I now want to suggest, to the contrary, that the persistence of a style may also be a topic for historical and sociological analysis. The techniques of verification which constitute a style are ineluctably embedded in, and depend upon, the socio-historical circumstances in which they are applied. In the case of the Ruby Range Sheep Steering Committee, Nadasdy provides us with a detailed account of those circumstances in terms of the bureaucratic power of the Canadian state. The hegemonic techniques of bureaucratic state science ensure the stability of prevailing standards of scientific objectivity in the Canadian North, and thus obstruct the full emergence and stabilisation of a genuine field style guided by the principles of epistemic neighbourliness.

The gist of this criticism is that Hacking has adopted the wrong theory of objectivity. He should have emphasised the historical dependency of reasoning techniques on stabilised social 
circumstances rather than their independence from those circumstances. ${ }^{13}$ This would be a good first step, but it does not go far enough. The problem with Hacking's account of objectivity is not just that he uses the wrong theory, but also that he uses too much theory. His excessive preoccupation with theories of power distracts him from the relevant concrete details of the phenomenon for which he purports to give an adequate explanation.

This is the crux of Martin Kusch's criticism of Hacking's stylistics of science. Kusch (2010, p. 169) argues that Hacking's account of objectivity treats styles "as if they were agents." This amounts to a "mystification" of styles which obscures the fact that power is not autonomous, but exercised by socially and historically embedded human agents. Indeed, Hacking (2012, p. 607) has recently argued that "styles are adapted to their environment, but like any creature they also change the environment to their advantage." To this alleged power of styles to extend their influence over the planet, Hacking gives the label "ecological imperialism," and he furthermore names Latour's model of the laboratory as extending into, and transforming, society as a "perfect" example of this phenomenon (Hacking 2012, p. 607). But acts of imperialism are performed, not by styles, but by co-ordinated human groups. Hacking's theory-driven acclamation of styles as autonomous agents serves to obstruct a sociological investigation into the causes of their remarkable power and persistence.

Because Kusch's critique focusses on Hacking's adaptation of Crombie's stylistics, it overlooks Hacking's own admission that "Michel Foucault['s] [...] influence on my idea of styles of reasoning is more profound than that of [...] Crombie" (Hacking, 1992, p. 12). In fact, the mystifying theoretical excess in Hacking's stylistics of science appears to be the result of his reading of Foucault. As Edward Said (2000/1982, p. 213) has argued, Hacking's use of Foucault is "overblown" and "go[es] to extremes." Said (2000/1982, p. 213) praises Foucault's methodological insight that a theory of knowledge and power is most effectively developed in micro-historical studies of particular social situations, but he also argues that this

\footnotetext{
${ }^{13}$ Hacking's subsequent attempts to more precisely articulate his theory of objectivity have been eclectic and speculative. In fact, as Kusch (2010, p. 169) notes, Hacking even once wondered if styles may not, after all, become autonomous of the social world, though this only in an unpublished manuscript. In a more recent, published work, Hacking (2010, pp. 81-82) suggests that styles are stabilised by "cognitive universals," which exist as part of our "human genetic envelope," but he then immediately qualifies this as "hand waving." For more sociologically decisive theories of objectivity, see: Bloor (1984); Haraway (1988); Kochan (2009a); and Porter (1994). Bloor (1983, ch. 6) argues that even the objective force of deductive reasoning techniques may lend itself to sociological explanation, a view I have endorsed and expanded upon (Kochan, 2008 and 2009b).
} 
methodological insight threatens to become a "theoretical trap" when Foucault shifts his analysis from micro-historical studies of particular situations to the dynamics of social life in general. According to Said, Hacking (1986/1981, p. 28) falls into this trap when he glosses Foucault's theory of knowledge and power with the statement that "[n]obody knows this knowledge; no one wields this power." The methodological insight at play here, it seems to me, is that the power of a scientific style cannot be explained solely in terms of the subjective will of the individual scientist. The scientist does not freely choose to follow a particular style; she rather feels compelled to do so. As I noted earlier, this feeling of compulsion marks the force of objective necessity. Hacking's methodological insight becomes a theoretical trap, however, when he furthermore concludes that a style's power operates independently of the sociohistorical circumstances of its application. He takes the genuine phenomenological insight that the objective application of a technique is not strictly a matter of individual subjective will, and confuses it with the theoretical claim that an objective technique must be autonomous of the micro-social and micro-historical circumstances in which it is constituted.

According to Said (2000/1982, p. 210), such excessive theorising results in a failure to recognise that no theory or system - and no style - exhausts the situation in which it develops or is applied, that a style will therefore elicit reactions from those whose concrete experiences or interpretations it serves to exclude, and that such reactions constitute genuine resistance to the perceived objectivity of that style. A scientific style will thus always be entangled in the complex social dynamics of the place where it is applied, as we saw was indeed the case with the Ruby Range Sheep Steering Committee. Said's analysis suggests that the over-theorising of situated knowledge-making practices may displace from view the concrete tensions permeating the social space in which objectivity emerges and is performed. In the case of Hacking, this displacement follows implicitly from his treatment of styles as autonomous agents. Not only does his account of objectivity threaten to efface the micro-dynamics of persistent epistemic resistance and accommodation, it is meant to dis-embed styles from the contingency of those dynamics. Nadasdy's ethnography helps us to re-embed Hacking's styles by re-situating the prevailing scientific reasoning techniques of the Ruby Range committee in the hegemonic structures of the Canadian state. On this interpretation, and in this particular case, the concept of an autonomous style may be seen as the subtle dissimulation of state power. As Nadasdy (2003, p. 264) concluded from his participation in the committee: "Although government officials never use - nor even explicitly refer to the use of - force in these processes, the coercive power of the state forms the backdrop against which they occur." He thus gives us the basis for an alternative account of the objectivity of styles with respect to northern field science, an account more amenable to sociological forms of explanation. Nevertheless, as I will argue in the next 
section, Nadasdy's analysis also ultimately falls victim to the threat of overblown theorising, and hence it too obscures the epistemic dynamics which render the field a distinctive site for scientific knowledge production.

\section{Putting a Pin in "State Power"}

There is a striking sense in which Nadasdy's analysis complements that of Hacking: they both seek to explain the same phenomenon, namely, the apparently overwhelming power of certain techniques to determine the shape of locally produced knowledge. However, whereas Hacking appeals to the autonomy of that power, Nadasdy emphasises its dependency on the hegemonic machinations of the bureaucratic state. In both cases, the role of locally situated agents in determining the content of the knowledge produced is dramatically reduced. In Nadasdy's account, all members of the Ruby Range Sheep Steering Committee, by accepting membership in that committee, effectively became "slots" in a state bureaucratic system. He argues that "[o]ne who takes for granted the institutional context of co-management cannot question the power relations that underlie that context" (Nadasdy, 2005, p. 220). Hence, when First Nation's members of the Ruby Range Sheep Steering Committee contributed their own knowledge of Dall sheep to the committee's deliberations "they get nowhere because government biologists and resource managers, regardless of their own personal beliefs and understandings, simply cannot implement management decisions based on such alternate conceptions of animals" (Nadasdy, 2003, p. 8) ${ }^{14}$ On Nadasdy's account, the formal commitment of committee members to follow the principles of epistemic neighbourliness was blocked by the overarching imperatives of state bureaucracy. He thus concludes that such attempts at cross-cultural scientific collaboration, "in both conception and practice, are incompatible with certain First Nations beliefs and practices" (Nadasdy, 2003, p. 9). The devastating implication is that, if First Nations wish to maintain their own epistemic autonomy, then they should refuse to enter into collaborative scientific ventures with the Canadian state. According to Nadasdy's analysis, epistemic neighbourliness is simply not possible under such conditions.

However, Nadasdy's assessment may be too strong. Indeed, as we have already seen, his general conclusion that collaborative projects are a subtle form of state imperialism, which work to uniformly strip First Nations peoples of their autonomy, seems at odds with certain modest details in his own ethnographical account. In attempting to explain why First Nations "get nowhere" in such collaborations, Nadasdy appeals to Max Weber's theory of bureaucracy. The

\footnotetext{
${ }^{14}$ Nadasdy (2011) offers a more recent, and even stronger, statement of this view.
} 
key passage he cites from Weber's account is: “[t]he 'objective' discharge of business primarily means a discharge of business according to calculable rules and "without regard for persons"" (Weber, 1991/1948, p. 215; cited in Nadasdy, 2003, p. 7, and 2005, p. 225). From this, Nadasdy concludes that bureaucratisation strips persons of agency, reducing them to "slots" in a system over which they have no control. Yet, just as Hacking relied on an overblown interpretation of Foucault, so it seems that Nadasdy employs an overblown interpretation of Weber.

In fact, Weber's sociology was thoroughly committed to a form of methodological individualism: he claimed that the basic explanatory unit in empirical sociology is the individual social actor rather than a collective entity (see Runciman, 1972, pp. 24f.). In Economy and Society, Weber (1978/1956, p. 14) wrote that, although such collective concepts as "the state" have genuine value in juridical and everyday usage,

$[w]$ hen reference is made in a sociological context to a state, a nation, a corporation, a family, or an army corps, or to similar collectivities, what is meant is, on the contrary, only a certain kind of development of actual or possible social actions of individual persons.

Moreover, in a letter from 1920, Weber wrote that "sociology, too, can only be practiced by proceeding from the action of one or more, few or many, individuals, that means, by employing a strictly 'individualist' method" (cited in Udehn, 2001, p. 98) ${ }^{15}$ On Nadasdy's account, bureaucratisation is a property of the state, a process by which the state extends its influence and erases opposition. Like Hacking, Nadasdy seems to have allowed a genuine methodological insight - that the meaning of an individual's actions in a bureaucracy may be underdetermined by her own subjective motives or intentions - to draw him into a theoretical trap - the view that individual actions in a bureaucracy must be ultimately explained in terms of the functional properties of an impersonal state. The implication is that bureaucratic science operates independently of local subjective will, and so these local subjectivities are ultimately irrelevant to its understanding.

Yet, Nadasdy provides empirical evidence which runs counter to these theoretical conclusions. Recall that state biologists were sometimes willing to downplay the importance of their own prevailing methods of verification in order to engage in productive collaboration with non-scientific members of the steering committee. In one instance, biologists modified their

\footnotetext{
${ }^{15}$ Heath (2014) provides a helpful synopsis of Weber's version of methodological individualism, alongside the rather different versions of Friedrich von Hayek, Karl Popper, and Jon Elster.
} 
aerial surveying methods partly in response to concerns from Kluane First Nation members that low-level helicopter flights were harassing sheep. In another instance, biologists were willing to include the data of a local outfitter into their survey even though that data differed radically from their own. These examples demonstrate that the style of reasoning employed by the committee was, in fact, responsive to local epistemic diversity, however modestly. In resisting the prevailing norms of state wildlife biology, the other committee members did sometimes manage to "get somewhere" after all.

Not too much should be made of this, however. The point I wish to make here is only that Nadasdy's theory of bureaucracy fails to exhaust the circumstances to which it is applied. The effects of local pressure on the committee's actions were hardly dramatic, but they were real. Nadasdy believes that co-management arrangements like the Ruby Range Sheep Steering Committee have been a complete failure. I suggest, instead, that they may have only been an overwhelming failure. The semantic space between 'overwhelming' and 'complete' is wide enough to accommodate the thin end of a wedge driven by the hope that cross-cultural scientific collaboration in the Canadian North, rather than being an idea which deserves to be abandoned, might still be critically reconstructed and improved upon. This is part of a wider hope that a genuine field style, a style responsive to the heterogeneity and fluid boundaries of local field sites, a style based on the principles of epistemic neighbourliness, may after all still be possible. In order to deflect the false and fearful image of modern bureaucratic science as a perfectly homogenous machine, driven forward by its own ineluctable internal logic, we need more attention to the heterogeneous and fragmentary nature of science in the field. In order to resist the corrosive acid of theory-driven cynicism, we need more emphasis on the rich empirical reality of local improvisation in response to the constructive ambiguities of natural field sites. In order to develop the idea of a style of reasoning distinctive for the field sciences, we need more examples of the ways in which radical cultural difference may co-exist with stable epistemic cooperation. The next two sections will explore these issues in more detail.

\section{Calibrating Scientific Interests}

In his historical survey of the science of Rangifer (the generic name for reindeer and caribou species), the anthropologist David Anderson argues that diverse groups in the Circumpolar North "have been knowingly or unknowingly engaged in a sort of partnership of inquiry for at least a century" (Anderson, 2000, p. 158). Definitive for such epistemic partnerships is the way scientific interests have been "calibrated" to the interests of local Aboriginal peoples (Anderson, 2000, p. 157). According to Anderson (2000, p. 154), the result 
of this calibration was a common interest in Rangifer which was "scientifically rigorous, empirically based and ethically sound." In my own terminology, Anderson presents historical evidence for cross-cultural collaborations in northern field science which were based on the principles of epistemic neighbourliness. He argues that the history of Rangifer science includes cases in which "local and academic voices merge and become indistinguishable" (Anderson, 2000, p. 163). In his view, contemporary attempts at similar collaboration - for example, the Ruby Range Sheep Steering Committee - pale in qualitative comparison to earlier collaborations (Anderson, 2000, p. 157). The knowledge produced in these earlier collaborations went beyond the discovery of new facts: it extended to the fundamental categories of Rangifer science, and also influenced the phenomenology of field observation by reconfiguring scientists' basic patterns of attention (Anderson, 2000, p. 163).

Anderson supports his argument with several historical cases. In one case, the early systematics of the genus Rangifer was developed in close co-operation with Aboriginal hunters (Anderson, 2000, pp. 159f.). In the $18^{\text {th }}$ Century, the first catalogued sample of R. t. pearyi was a gift from the Chipewyan guide of the explorer and naturalist Samuel Hearne, and the earliest prototype of naturalist Johann Friedrich Gemlin's R. t. caribou was chased down by Métis hunters on the St. Lawrence River. On a more conceptual level, the taxonomic sub-specification for "woodland caribou" was taken from traditional Mi'kmaq classification. Anderson concludes that the very taxon of Rangifer, along with many of its sub-specifications, is the result of the successful calibration of scientific to local Aboriginal interests. ${ }^{16}$

In another case, Anderson (2000, pp. 161f.) argues that the received doctrine that Rangifer species subdivide into distinct "herds" with fidelity to specific "calving grounds" was also the product of intensive communication between Aboriginal hunters and non-Aboriginal field scientists during the last century. In Québec/Labrador, an unnamed Naskapi informant was credited with the late $19^{\text {th }}$-century idea that the region's R. t. caribou species divides into three distinct herds which overwinter in discrete ranges in Northern Québec. As recently as 1988, the Torngat Mountain herd was formally identified in Northern Québec on the basis of "incidental reports from residents of the Ungava." A similar calibration of scientific to Aboriginal interests also occurred in the Northern Yukon. In his 1935 book, Alaska-Yukon Caribou, Olaus Murie credits an "Indian at Old Crow Village" for recognising the fact that "northern herds" follow a migratory route to the south coast (cited in Anderson, 2000, p. 162). More recent work suggests that, as early as the 1940s, Gwich'in hunters consistently identified a preference among R.t.

\footnotetext{
${ }^{16}$ Anderson's paper also includes a case from Soviet Siberia, and he furthermore argues that differences in state organisation (socialist vs. liberal democratic) also affected the calibration of scientific to Aboriginal interests, and hence the taxonomy of Rangifer as well.
} 
granti for certain calving localities, an idea taken up by biologists in the late 1950s. Anderson (2000, p. 162) notes that this blending of Aboriginal and non-Aboriginal interest in the coproduction of Rangifer science was not only "seamless and anonymous," but also surprisingly rapid. By the mid-1970s, biologists had carved boreal North America into discrete territories representing the near exclusive ranges of particular herds. Anderson writes that the quick adoption of this "common paradigm" corresponded to a "rapid amnesia" about previous dispersion models. This appears to be a clear case of stable cross-cultural collaboration giving rise to an objective scientific category, of epistemic neighbourliness supporting a style of reasoning which availed itself of the heterogeneous epistemic resources of the field.

Anderson (2000, p. 163) insists that these historical cases do not pick out anything unusual or new about field practice in the Canadian North: "In this boreal community of scholars and locals, as in any other community, it is only common sense that these interested groups should be talking, comparing models, and learning from each other." In his view, such cross-cultural collaboration is a persistent feature of northern field science. It represents, in other words, a distinct and stable regional style of scientific reasoning, a style grounded in the principles of epistemic neighbourliness. Yet Anderson also observes that this style is sensitive to social and historical circumstances, and so its strength may vary in response to broader social and political changes. According to his analysis, the sensitivity of the style reflects a flexibility in the calibration of scientists' interests. For example, he notes that, at the height of centralised state wildlife management in the 1960s and 1970s, there was an aggressive neglect of local Aboriginal interests (Anderson, 2000, p. 156). Instead, the interests of government scientists in Rangifer became strongly calibrated, during this Cold War period, to the imperatives of nation state building.

As Robert McCandless has shown, these changes in wildlife science tracked changes in the social order of Yukon society. This is dramatically evident in the period after 1942, when the U.S. Army completed construction of the Alaskan Highway. McCandless (1985, p. 68) writes that Yukon residents were "bowled over" by the sudden disappearance of their comfortable isolation. Along with a sudden influx of new residents, the road carried with it broadcast radio, the telephone, and mass-circulation newspapers: "The old bureaucratic methods were unable to adapt and the Yukon's old communications archipelago dissolved in the warm sea of modern communications" (McCandless, 1985, p. 86). According to McCandless (1985, p. 86), the most important change was to people's perception of the land. Previously, Aboriginal inhabitants had been on a virtually equal footing with non-Aboriginal inhabitants (McCandless 1985, p. 44). Now, a process of separation, both social and economic, began. At the same time, "wildlife became detached from the landscape, from any local, site-specific understanding of 
varieties and abundance, only to become a free-floating, Territory-wide system" (McCandless 1985, p. 93). Anderson (2000, p. 156) makes the complementary observation that these changes not only led to an aggressive neglect of Aboriginal interests, but also to profound changes in Rangifer systematics, with consensus forming around the notion of "a single generic and specific type of Rangifer which could be measured and understood without much attention to local categories and observations."

According to Anderson, this period marks the nadir of a cross-cultural collaborative style in the North which has always been part of Rangifer science. Scientific interests became badly calibrated with Aboriginal interests in the mid- $20^{\text {th }}$ century, but they did not entirely lose contact with them, no more than they entirely lost contact with the specificities of Rangifer itself. The idea of a hegemonic state which completely suppresses the epistemic interests of local actors, assigning them to "slots" in an impersonal scientifico-governmental system, is a theoretician's fantasy as well as a practical impossibility. As we will see in the next section, the inevitable ambiguities and incoherencies of state practice provide unintended, and often unacknowledged, opportunities for local actors to exercise influence on the productive epistemic processes in which they are involved. The recognition and encouragement of such opportunities must, in my view, play an ineliminable role in any self-stabilising field style.

\section{Constructive Ambiguity in Cross-Cultural Wildlife Management}

As the anthropologist Harvey Feit writes, in the 1920s and 1930s the James Bay region of Northern Québec suffered a serious decline in beaver populations, brought on by a boom in fur prices and the increasing accessibility of the region (Feit, 2005, p. 271). In the coastal community of Waskaganish (Rupert's House, at the time), the situation deteriorated to the point where the beaver had almost disappeared and the Waskaganish Crees' traditional system of family hunting territories (Ndoho Istchee) had been seriously disrupted by outside trappers (Feit, 2005, pp. 272f.). In 1929, after extended conversations with Waskaganish Crees, the Hudson's Bay Company (HBC) trader, James Watt, drafted a plan to conserve the beaver by recognising and supporting the authority of the Waskaganish system of family hunting territories, possibly through some sort of lease. Since his spouse, Maude Watt, was both a Québécoise and a wellknown personality in the province, they agreed that she would travel to Québec City and directly petition the government for support. In 1932, the province set up a beaver reserve north and east of Waskaganish on $18,500 \mathrm{~km}^{2}$ of land. However, rather than granting a lease to the Waskaganish Cree, the province granted it to Maude Watt instead. A year later, the lease was transferred to the HBC. This was neither what the Crees had wanted nor what the Watts had 
initially proposed. Rather than recognising the authority of the Waskaganish hunting system, the government had instead moved to assert its exclusive authority over the land and beaver.

According to Feit (2005, p. 273), through the introduction of beaver reserves the Québec Government sought to diminish Cree control over the land and the authority of their hunting practices. The programme thus helped assert Canada's northern sovereignty during World War II and into the Cold War by facilitating its transition to "a modern nation state governing the north by means of rational and scientific management of resources, lands and people" (Feit, 2005, p. 273). Nevertheless, the management system could not succeed without Cree recognition and involvement. In 1933, 14 Crees were appointed "game guardians" on the new Waskaganish beaver reserve, with an annual remuneration of C\$100. Each was issued a badge and given an "impressive document with a fancy seal as his certificate of office" (Feit, 2005, p. 274). Their job was to map the locations of beaver lodges, report incidents of trespassing, and help to fight forest fires. The Waskaganish Crees quickly saw that the government programme provided both intentional and unintentional support for their own interests. In the former instance, it successfully conserved the beaver populations. In the latter case, despite the government's claim to de jure power over the land, beaver, and local inhabitants, the Crees used their status as game guardians as a new source of de facto power, which they exercised to limit trespass and so strengthen the integrity of their system of family hunting territories.

In the 1970s, a noted Cree story teller and historian could thus claim that Waskaganish Crees participated in the programme because it "made sense" from a Cree perspective (Feit, 2005, p. 274). Despite the state's imperialist motivations, including their plan to further diminish Cree sovereignty, Crees chose to support and participate in the programme without, however, claiming credit for it. They did not identify the beaver reserve programme with their own conservation practices, but they still viewed it as benefiting their own interests. In 1936, several prominent Waskaganish Crees told an official from the Federal Department of Indian Affairs that they were "very pleased" with the beaver reserve programme (Feit, 2005, p. 274). Given the ambiguities in the way power was distributed in the programme, the Indian Affairs official may well have mistaken this for an endorsement of the government's own plan, rather than as a sign that the Crees had, to a degree, successfully adapted the programme to their own interests.

One could speak here of a calibration of state to Aboriginal interests, but only if interests are distinguished from intentions. It was in the interest of the state to enrol Waskaganish Crees into the beaver reserve programme, but this enrolment had the unintended consequence of strengthening the local authority of their family hunting territory system. There is a sense in which the government did not know what it was doing. This incoherence allowed Crees to make 
sense of and support the government's programme on their own terms: they found government actions intelligible within the scope of their own epistemic tradition. Insofar as the success of the beaver reserves programme evinces a distinctive style of reasoning, it highlights a crucial aspect of Hacking's styles concept. Recall his stipulation that a style is as much about doing as it is about thinking: it should conjure up visions of science as an engaged practice, a bodily involvement or intervention in the world. Styles are, in other words, as much about the hand as they are about the head. Indeed, the present case suggests that a style may sometimes have more to do with hand than head. On the side of the government, the head did not well understand what the hand was doing. Yet the result was a successful scientific programme in cross-cultural wildlife management. The head would, however, soon twig to the unintended conditions of its success, and the corresponding style would thus become more explicit and deliberate.

When he had drafted the 1929 Waskaganish proposal, James Watt had thought that the 14 game guardian positions would be rotated so as to distribute the modest honoraria more widely within the community. However, it quickly became clear that the best qualified guardians were the hunting leaders (Ndoho Ouchimauch) whose family hunting territories (Ndoho Istchee) overlapped with the beaver reserves. The game guardianships thus went to the local hunting leaders, elevating their status and strengthening their local authority over their traditional hunting territories. Hence, as Feit (2005, p. 276) writes, "the operation of the beaver reserves started to be adapted to the Cree system of hunting territories." What had begun as the largely unintentional calibration of Canadian to Cree interests became increasingly intentional as HBC and Canadian officials recognised the value of local Cree conservation practices. By the mid1930 s, there was broad agreement that the restoration of the beaver populations required the conjoint recognition of Aboriginal rights and authority. What was emerging was "a complex, plural form of game management," in which two different governmental and conservation regimes were viewed as complementary (Feit, 2005, pp. 276-277). Yet, no one really understood how these radically different regimes could effectively work together.

By 1942, the beaver reserve programme was being actively modelled on the Cree system of family hunting grounds (Feit, 2005, p. 278). At the end of that year, the Deputy Minister of Indian Affairs wrote to the Commissioner of the Royal Canadian Mounted Police (RCMP) that:

[the RCMP] rightly stresses the importance of trapping ground rights and the following explanation of our tallyman system will show that we also not only recognize these rights but have put them to use in our administration of Fur Preserves. [...] When it is borne in mind that a Tallyman [Ndoho Ouchimau, or "hunting leader"] is the head of a family; that a district is a family trapping ground [Ndoho Istchee, or "family hunting territory"]; that a 
section is the area trapped over by a whole tribe or band and that all boundaries are laid out by the Indians themselves, it is apparent that we have not only adhered strictly to Indian custom but have actually improved on it. (Cited in Feit, 2005, p. 279.)

In this passage, a senior Canadian government official, in the course of exercising his legally mandated authority, explicitly recognises Cree rights and land tenure, and affirms the authority of the Cree hunting territory system. According to Feit (2005, p. 279), such recognitions and affirmations "were repeated in various forms over the course of the next two decades." During the entire lifetime of the beaver reserve programme, spanning from the 1930s to the 1960s, "[b]oth extensive Cree autonomy and extensive co-management were the practice" (Feit, 2005, p. 279). The stability and success of this practice was constitutive of an objective, cross-cultural style of scientific reasoning. Reliable scientific standards were effectively developed, deployed, and sustained over a generation within a heterogeneous domain of dramatic and unsuppressed epistemic difference. The result was a success for both the principles of epistemic neighbourliness and for the objective integrity of the northern field sciences.

\section{Conclusion: A Postcolonial Style for the Field}

In a recent book, John Sandlos (2007, p. 8) throws powerful light on the "historical antagonism" between Aboriginal peoples and state scientists in the Canadian North. He lays out ample evidence for how the Canadian state, from the end of the nineteenth century to around 1970, deployed intensive regimes of scientific wildlife management in order to gain administrative control over Aboriginal lives: "[t]he coercive programs designed to alter the subsistence cycle of Aboriginal people represented perhaps the most profound diffusion of state power over their basic subsistence activities" (Sandlos, 2007, p. 241). Sandlos (2007, p. 242) draws on Foucault's theory of disciplinary power to characterise state wildlife science as a "totalizing influence $[. .$.$] that allowed the state to manage and regulate the most basic aspects of$ everyday life among the Dene and the Inuit." His book is thus a striking illustration of the entanglement of science and empire, of the way science has served imperium by cloaking the agonistic extension of state power under the apparently indifferent garments of scientific practice. Lynn Nyhart has called this the "naturalization of empire" (Nyhart, 2011, p. 54).

By deconstructing the stubborn distinction between science and empire, Sandlos contributes to a growing literature in postcolonial science studies. ${ }^{17}$ But Sandlos does not limit

\footnotetext{
${ }^{17}$ General works in postcolonial science studies include: Anderson and Hecht (2002); Anderson and Adams (2008); Harding (2011, 2008, 2006 and 1998); Hess (1995); McNeil (2005); Nader
} 
himself to historical argument. On the penultimate page of his narrative, he expresses scepticism about contemporary cross-cultural scientific initiatives in the Canadian North, taking as his warrant Nadasdy's ethnography of the Ruby Range Sheep Steering Committee: "Paul Nadasdy's recent study of wildlife co-management initiatives in the Yukon suggests that a large measure of the colonialism inherent to previous conservation efforts persists in the Canadian North" (Sandlos, 2007, p. 243). Together, Sandlos's history and Nadasdy's ethnography are meant to form an interlocking picture of bureaucratic state science relentlessly extending its power, ineluctably effacing diversity in ever more remote northern field sites.

Without wishing to challenge the general accuracy of this account, I have attempted in this paper to point out its limitations. These limitations are, I have suggested, contiguous with the methodological limitations which accompany the treatment of natural field sites as extensions of the laboratory. There is no doubt that concepts from laboratory studies may be usefully applied to studies of the field. But, as a general theory of the field sciences, a model which emphasises the agonistic extension of power beyond the walls of the laboratory fails to exhaust the rich epistemic potentialities of the field (and perhaps also of the lab). In particular, it distracts from evidence for a style of reasoning distinctive of the field, a style which I have argued is based on the principles of epistemic neighbourliness. This is a style in which scientific meaning is created in a spirit of collaboration rather than of contestation. Instead of being a style which reacts to the inflexible imperatives of hegemonic state building, this is a style sensitive to the indigenous conditions of natural field sites, to the fluidity of their boundaries and the epistemic diversity of the participants who inhabit them together.

By digging beneath the slick surface of science construed as agonistic trials of strength, and thereby exposing the delicate and durable tendrils of epistemic neighbourliness which distinguish the field sciences as a unique object of study, we may contribute to a deeper understanding of the variegated ways in which human beings join together in making sense of the natural world. This suggests a different postcolonial analysis from the kind offered by Nadasdy and Sandlos, one which seeks to push the decolonisation project one step further. Rather than reproducing the dualistic image of a Manichean struggle between two incommensurable knowledge systems, we might instead attune ourselves to the profound ways in which reliable natural knowledge can grow from the rich soil of sometimes radical cultural

(1996); Schaffer, et al. (2009); and Seth (2009). Works which specifically discuss science and indigenous knowledge include: Agrawal (1995); Anderson and Nuttall (2004); Bala and Joseph (2007); Bravo (1996 and 2000); Cajete (1999); Cruikshank (1981, 2001 and 2005); Govind (2014); Scott (1996); TallBear (2013a and 2013b); Turnbull (2000); Turnbull and WatsonVerran (1995); Verran (1998, 2002 and 2013); Ween (2011); Ween and Riseth (2012). 
difference. This is what I have tried to do in this paper. Along the way, I hope to have also put new tools in the hands of friends of the field sciences, so that they too may further articulate a unique style for the field.

\section{Acknowledgements}

Many people have positively influenced my thoughts and feelings about the topics discussed in this paper. None of them are responsible for the infelicities of the final result. They include: David Anderson, Darlene Auger, David Bloor, Michael Bravo, Jim Brown, Eugene Buffalo, Cecil and Marie Crier, Julie Cruikshank, Larry and Lorraine Cutarm, Harvey Feit, Sandra Harding, Tim Ingold, Emma Kowal, Martin Kusch, Billy-Joe Laboucan, Betty Lafferty Letendre, Mike Lynch, Kohkom Emma Rabbit, Simon Schaffer, Estheranna Stäuble, Jodi Stonehouse, and Dorothy Thunder. Parts of the paper were presented to audiences in Columbia, South Carolina, and Cleveland, Ohio, as well as to members of the School of Social Science at the University of Aberdeen, where I enjoyed the intellectual friendship and generous hospitality of David Anderson's ERC-funded Arctic Domus research group. My thanks to them all - hay hay!

\section{References}

Agrawal, A. (1995). Dismantling the Divide between Indigenous and Scientific Knowledge. Development and Change, 26, 413-439.

Anderson, D. G. (2000). Rangifer and Human Interests. Rangifer, 20, 153-174.

Anderson, D. G. \& Nuttall, M. (Eds.). (2004). Cultivating Arctic Landscapes: Knowing and Managing Animals in the Circumpolar North. Oxford: Berghahn.

Anderson, W. \& Adams, V. (2008). Pramoedya's Chickens: Postcolonial Studies of Technoscience. In: Hackett, E. O., Amsterdamska, O., Lynch, M., \& Wajcman, J. (Eds.), The Handbook of Science and Technology Studies, $3^{\text {rd }}$ edition (pp. 181-204). Cambridge MA: The MIT Press.

Anderson, W. and Hecht, G. (Eds.). (2002). Postcolonial Technoscience, special themed section of Social Studies of Science, 32.

Bala, A., \& Joseph, G. C. (2007). Indigenous Knowledge and Western Science: The Possibility of Dialogue. Race \& Class, 49, 39-61.

Barnes, B. (1983). Social Life as Bootstrapped Induction. Sociology, 17, 524-545.

Barnes, B. (2001). Practice as Collective Action. In: Schatzki, T. R., Knorr Cetina, K., \& von Savigny, E. (Eds.), The Practice Turn in Contemporary Theory (pp. 17-28). London: Routledge.

Berg, M. (1996). A Fruitful A-Modernism of a Lingering Modernist: Commentary on Bruno Latour's 'On Objectivity'. Mind, Culture, and Activity, 3, 252-258.

Bloor, D. (1983). Wittgenstein: A Social Theory of Knowledge. London: Macmillan.

Bloor, D. (1984). A Sociological Theory of Objectivity. In: Brown, S. C. (Ed.), Objectivity and Cultural Divergence (pp. 229-254). Cambridge: Cambridge University Press.

Bocking, S. (2011). Indigenous Knowledge and the History of Science, Race, and Colonial Authority in Northern Canada. In: Baldwin, A., Cameron, L., \& Kobayashi, A. (Eds.), Rethinking the Great White North: Race, Nature, and the Historical Geographies of Whiteness in Canada (pp. 39-61). Vancouver: UBC Press.

Bravo, M. T. (1996). The Accuracy of Ethnoscience: A Study of Inuit Cartography and CrossCultural Commensurability (Manchester Papers in Social Anthropology no. 2). Manchester: Department of Social Anthropology, University of Manchester. 
Bravo, M. T. (2000). Cultural Geographies in Practice: The Rhetoric of Scientific Practice in Nunavut. Ecumene, 7, 468-474.

Cajete, G. (1999). Native Science: Natural Laws of Interdependence. Sante Fe: Clear Light Publishers.

Cruikshank, J. (1981). Legend and Landscape: Convergence of Oral and Scientific Traditions in the Yukon Territory. Arctic Anthropology, 43, 67-93.

Cruikshank, J. (1998). The Social Life of Stories: Narrative and Knowledge in the Yukon Territory. Lincoln, NB: University of Nebraska Press.

Cruikshank, J.( 2001). Glaciers and Climate Change: Perspectives from Oral History. Arctic, 54, 377-393.

Cruikshank, J. ( 2005). Do Glaciers Listen? Local Knowledge, Colonial Encounters and Social Imagination. Vancouver: UBC Press.

Cruikshank, J., in collaboration with Sidney. A., Smith, K. \& Ned, A. (1991). Life Lived Like a Story: Life Stories of Three Yukon Native Elders. Vancouver: UBC Press.

Dear P. (2003). Intelligibility in Science. Configurations, 11, 145-161.

Dear, P. (2006). The Intelligibility of Science: How Science Makes Sense of the World. Chicago: University of Chicago Press.

Elam, M. (1999). Living Dangerously with Bruno Latour in a Hybrid World. Theory, Culture \& Society, 16, 1-24.

Feit, H. A. (2005). Re-Cognizing Co-Management as Co-Governance: Visions and Histories of Conservation at James Bay. Anthropologica, 47, 267-288.

Fortmann, L., (Ed.). (2008). Participatory Research in Conservation and Rural Livelihoods: Doing Science Together. Oxford: Wiley-Blackwell.

Freeman, M. M. R. (1985). Appeal to Tradition: Different Perspectives on Arctic Wildlife Management. In: Brøsted, J., Dahl, J., Gray, A., Gulløw, H. C., Henriksen, G., Jørgensen, J. B., \& Kleivan, I. (Eds.), Native Power: The Quest for Autonomy and Nationhood of Indigenous Peoples (pp. 264-281). Oslo: Universitetsforlaget AS.

Govind, M. ( 2014). Modern Science and Indigenous Techniques: Subalternity of Knowledge Production in India. In: Pankaj, A. K., \& Pandey, A. K. (Eds.), Subalternity, Exclusion and Social Change in India (pp., 118-148). New Dehli: Cambridge University Press.

Hacking, I. (1982). Language, Truth and Reason. In: Hollis, M., \& Lukes, S. (Eds.), Rationality and Relativism (pp. 48-66). Oxford: Blackwell.

Hacking, I. (1986/1981). The Archaeology of Foucault. In: Hoy, D. C. (Ed.), Foucault: A Critical Reader (pp. Hoy, 27-40). Oxford: Basil Blackwell.

Hacking, I. (1992). 'Style' for Historians and Philosophers. Studies in History and Philosophy of Science, 23, 1-20.

Hacking, I. (2010). Husserl on the Origins of Geometry. In: Hyder, D., \& Rheinberger, H.-J. (Eds.), Science and the Life-World: Essays on Husserl's 'Crisis of European Sciences' (pp. 64-82). Stanford: Stanford University Press.

Hacking, I. (2012). 'Language, Truth and Reason' 30 Years Later. Studies in History and Philosophy of Science, 43, 599-609.

Hallowell, A. I. (1969). Ojibwa Ontology, Behavior, and World View. In: Diamond, S. (Ed.), Primitive Views of the World (pp. 49-82). New York: Columbia University Press.

Haraway, D. (1988). Situated Knowledges: The Science Question in Feminism and the Privilege of Partial Perspective. Feminist Studies, 14, 575-599.

Haraway, D. (1994). A Game of Cat's Cradle: Science Studies, Feminist Theory, Cultural Studies. Configurations, 2, 59-71.

Harding, S. (1998). Is Science Multicultural? Postcolonialisms, Feminisms, and Epistemologies. Bloomington: Indiana University Press.

Harding, S. (2006). Science and Social Inequality: Feminist and Postcolonial Issues. Champaign: University of Illinois Press.

Harding, S. (2008). Sciences from Below: Feminisms, Postcolonialities, and Modernities. Durham NC: Duke University Press. 
Harding, S. (Ed.). (2011). The Postcolonial Science Studies Reader. Durham NC: Duke University Press.

Heath, J. (2014). Methodological Individualism. In: Zalta, E. N. (Ed.), The Stanford Encyclopedia of Philosophy. URL = $<$ http://plato.stanford.edu/archives/fall2014/entries/methodological-individualism/>.

Hess, D. J. (1995). Science \& Technology in a Multicultural World: The Cultural Politics of Facts \& Artifacts. New York: Columbia University Press.

Inglis, J. T. (Ed.) (1993). Traditional Ecological Knowledge: Concepts and Cases. Ottawa: International Program on Traditional Ecological Knowledge \& International Development Research Centre.

Ingold, T. (2000). The Perception of the Environment: Essays in Livelihood, Dwelling and Skill. London: Routledge.

Kochan, J. (2008). Realism, Reliabilism, and the 'Strong Programme' in the Sociology of Scientific Knowledge. International Studies in the Philosophy of Science, 22(1), 21-38.

Kochan, J. (2009a). Popper's Communitarianism. In: Parusniková, Z., \& Cohen, R. S. (Eds.), Rethinking Popper (Boston Studies in the Philosophy of Science, 272) (pp. 287-303). Berlin: Springer.

Kochan, J. (2009b). The Exception Makes the Rule: Reply to Howson. International Studies in the Philosophy of Science, 23(2), 213-216.

Kochan, J. (2010). Latour's Heidegger. Social Studies of Science, 40(4), 579-598.

Kochan, J. (2011). Getting Real with Rouse and Heidegger. Perspectives on Science, 19(1), 81115.

Kochan, J. (2013). Subjectivity and Emotion in Scientific Research. Studies in History and Philosophy of Science, 44, 354-362.

Kochan, J. (2015a). Putting a Spin on Circulating Reference, or How to Rediscover the Scientific Subject. Studies in History and Philosophy of Science, 49, 103-107.

Kochan, J. (2015b). Reason, Emotion, and the Context Distinction. Philosophia Scientiae 19, 103-107.

Kohler, R. E. (2002). Landscapes and Labscapes: Exploring the Lab-Field Border in Biology. Chicago: University of Chicago Press.

Kohler, R. E. (2011). History of Field Science: Trends and Prospects. In: Vetter, J. (Ed.), Knowing Global Environments: New Historical Perspectives on the Field Sciences (pp. 212-240). New Brunswick: Rutgers University Press.

Kuklick, H., \& Kohler, R. E. (1996). Introduction. In: Kuklick, H., \& Kohler, R. E. (Eds.), Science in the Field (OSIRIS, $2^{\text {nd }}$ series, vol. 11) (pp. 1-14).

Kusch, M. (2010). Hacking's Historical Epistemology: A Critique of Styles of Reasoning. Studies in History and Philosophy of Science, 41, 158-173.

Latour, B. (1983). Give Me a Laboratory and I Will Raise the World. In: Knorr-Cetina, K. D., \& Mulkay, M. (Eds.), Science Observed: Perspectives on the Social Study of Science (pp. 141-170). London: SAGE.

Latour, Bruno. 1987. Science in Action: How to Follow Scientists and Engineers through Society. Cambridge MA: Harvard University Press.

Latour, B. (1990). The Force and Reason of Experiment. In: Le Grand, H. E. (Ed.), Experimental Inquiries (pp. 49-80). Dordecht: Kluwer.

Latour, B. (1999). Pandora's Hope: Essays on the Reality of Science Studies. Cambridge MA: Harvard University Press.

Latour, B., \& Strum, S. (1987). Redefining the Social Link: from Baboons to Humans. In: MacKenzie, D., \& Wajcman, J. (Eds.), The Social Shaping of Technology, $2^{\text {nd }}$ edn. (pp. 116-125). Maidenhead: Open University Press.

Latour, B., \&Woolgar, S. (1979). Laboratory Life: the Social Construction of Scientific Facts. Los Angeles: SAGE.

McCandless, R. G. (1985). Yukon Wildlife: A Social History. Edmonton: University of Alberta Press. 
Michel, H., \& Gayton, D. (Eds.) (2002). Linking Indigenous Peoples' Knowledge and Western Science in Natural Resource Management: Conference Proceedings (SIFERP Series No. 4). Kamloops: Southern Interior Forest Extension Research Partnership. URL: <www.siferp.org/sites/default/files/forrex_series/SS4.pdf>. Accessed: 21 May 2014.

McNeil, M. (Ed.) (2005). Postcolonial Technoscience, special issue of Science and Culture, $14(2)$.

Nadasdy, P. (2003). Hunters and Bureaucrats: Power, Knowledge, and Aboriginal-State Relations in the Southwestern Yukon. Vancouver: UBC Press.

Nadasdy, P. (2005). The Anti-politics of TEK: The Institutionalization of Co-management Discourse and Practice. Anthropoligica, 47, 215-232.

Nadasdy, P. (2011). 'We Don't Harvest Animals; We Kill Them': Agricultural Metaphors and the Politics of Wildlife Management in the Yukon. In: Goldman, M. J., Nadasdy, P., \& Turner, M. D. (Eds.), Knowing Nature: Conversations at the Intersection of Political Ecology and Science Studies (pp. 135-151). Chicago: University of Chicago Press.

Nader, L. (Ed.) (1996). Naked Science: Anthropological Inquiry into Boundaries, Power, and Knowledge. London: Routledge.

Nyhart, L. K. (2011). Emigrants and Pioneers: Moritz Wagner's 'Law of Migration' in Context. In: Vetter, J. (Ed.), Knowing Global Environments: New Historical Perspectives on the Field Sciences (pp. 39-58). New Brunswick: Rutgers University Press.

Porter, T. M. (1994). Objectivity as Standardization: The Rhetoric of Impersonality in Measurement, Statistics, and Cost-Benefit Analysis. In: Megill, A. (Ed.), Rethinking Objectivity (pp., 197-237). Durham NC: Duke University Press.

Powell, R. C. (2002). The Sirens' Voices? Field Practices and Dialogue in Geography. Area, 34, 261-272.

Powell, R. C. (2007). 'The Rigours of an Arctic Experiment': The Precarious Authority of Field Practices in the Canadian High Arctic, 1958-1970. Environment and Planning A, 39, 1794-1811.

Powell, R. C. (2008). Becoming a Geographical Scientist: Oral Histories of Arctic Fieldwork. Transactions of the Institute of British Geographers, 33, 548-565.

Rouse, J. (1987). Knowledge and Power: Toward a Political Philosophy of Science. Ithaca: Cornell University Press.

Runciman, W. G. (1972). A Critique of Max Weber's Philosophy of Social Science. Cambridge: Cambridge University Press.

Said, E. (2000/1982). Travelling Theory. In: Bayoumi, M., \& Rubin, A. (Eds.), The

Edward Said Reader (pp. 195-217). New York: Vintage Books.

Sandlos, J. (2007). Hunters at the Margin: Native People and Wildlife Conservation in the Northwest Territories. Vancouver: UBC Press.

Schaffer, S., Roberts, L., Raj, K., \& Delbourgo, J. (Eds.) (2009). The Brokered World: GoBetweens and Global Intelligence, 1770-1820. Sagamore Beach: Science History Publications.

Scott, C. (1996). Science for the West, Myth for the Rest? The Case of James Bay Cree Knowledge Construction. In: Nader, L. (Ed.), Naked Science: Anthropological Inquiry into Boundaries, Power, and Knowledge (pp. 69-86). London: Routledge.

Seth, S. (Ed.). (2009). Science, Colonialism, Postcolonialism, special issue of Postcolonial Studies, 12.

Shapin, S. (1998). Placing the View from Nowhere: Historical and Sociological Problems in the Location of Science. Transactions of the Institute of British Geographers, 23, 5-12.

Sismondo, S. (2010). An Introduction to Science and Technology Studies, $2^{\text {nd }}$ edn. Chichester: Wiley-Blackwell.

Smith, B. (2004). Applying the Knowledge, Experience and Values of Yukon Indian People, Inuvialuit, and Others in Conservation Decisions: Summaries of 55 Yukon Projects, 1985-2003. Whitehorse: Department of Environment, Government of Yukon. 
Spaeder, J. J., \& Feit, H. A., (Eds.) (2005). Co-Management and Indigenous Communities: Barriers and Bridges to Decentralized Resource Management, special issue of Anthropologica, 47.

Star, S. L. (1991). Power, Technology and the Phenomenology of Conventions: On Being Allergic to Onions. In: Law, J. (Ed.), A Sociology of Monsters: Essays on Power, Technology and Domination (pp. 26-56). London: Routledge.

TallBear, K. (2013a). Genomic Articulations of Indigeneity. Social Studies of Science, 43, 509533.

TallBear, K. (2013b). Native American DNA: Tribal Belonging and the False Promise of Genetic Science. Minneapolis: University of Minnesota Press.

Turnbull, D. (2000). Masons, Tricksters and Cartographers: Comparative Studies in the Sociology of Scientific and Indigenous Knowledge. Amsterdam: Harwood.

Turnbull, D, \& Watson-Verran, H. (1995). Science and Other Indigenous Knowledge Systems. In: Jasanoff, S., Markle, G. E., Petersen, J. C., \& Pinch, T. (Eds.), Handbook of Science and Technology Studies (pp. 115-139). London: SAGE.

Udehn, L. (2001). Methodological Individualism: Background, History and Meaning. London: Routledge.

Verran, H. (1998). Re-imagining Land Ownership in Australia. Postcolonial Studies, 1, 237254.

Verran, H. (2002). A Postcolonial Moment in Science Studies: Alternative Firing Regimes of Environmental Scientists and Aboriginal Landowners. Social Studies of Science, 32, 729762.

Verran, H. (2013). Engagements between Disparate Knowledge Traditions: Toward Doing Difference Generatively and in Good Faith. In: Green, L. (Ed.), Contested Ecologies: Dialogues in the South on Nature and Knowledge (pp. 141-161). Cape Town: HSRC Press.

Vetter, J. (Ed.) (2011). Knowing Global Environments: New Historical Perspectives on the Field Sciences. New Brunswick: Rutgers University Press.

Weber, M. (1991/1948). Bureaucracy. In: Gerth, H. H., \& Mills Wright, C. (Eds.), From Max Weber: Essays in Sociology (pp. 196-244). London: Routledge.

Weber, M. (1978/1956). Economy and Society: An Outline of Interpretive Sociology, eds. Roth, G., \& Wittich, C. Berkeley: University of California Press.

Ween, Gro. B. (2012). Enacting Human and Non-human Indigenous: Salmon, Sami and Norwegian Natural Resource Management. In: Ellefsen, R., Sollund, R., \& Larson, G. (Eds.), Eco-Global Crimes: Contemporary Problems and Future Challenges (pp. 295313). London: Ashgate.

Ween , G. B., \& Riseth, J. A. (2011). Doing is Learning: Analysis of an Unsuccessful Attempt to Adapt TEK/IK Methodology to Norwegian Sámi Circumstances. Acta Borealia, 28, 228-242.

Weir, J. (2005-06). Advancement of the Alpine Tree \& Shrubline and Implications for Dall Sheep Habitat Loss. In: Henry, J. D., Krebs, C. J., Hofer, A., Kenney, A. J., \& Chilibeck, A. (Eds.), The Kluane Ecological Monitoring Project Annual Report 2005/2006 (pp. 2324). URL: <www.taiga.net/reports/kemp_2005-06.pdf>. Accessed: 13 May 2014. 